\title{
Youth in Superdiverse Societies
}

Growing up with Globalization, Diversity, and Acculturation

\section{Edited by Peter F. Titzmann and Philipp Jugert}

First published 2020

ISBN 13:978-1-138-48838-0 (hbk)

ISBN 13: 978-1-138-48839-7 (pbk)

ISBN 13: 978-1-351-04026-6 (ebk)

\section{Chapter 11}

Ethnic majority and minority youth in multicultural societies

Sabahat Cigdem Bagci and Adam Rutland

CC BY-NC-ND 4.0

Routledge

Taylor \& Francis Group LONDON AND NEW YORK 


\title{
Ethnic majority and minority youth in multicultural societies
}

\author{
Sabahat Cigdem Bagci and Adam Rutland
}

Today, as a result of significant waves of immigration and globalization, many social environments that surround young people are extremely culturally diverse. Recently collected data demonstrates that not only in the US, but also in various parts of Europe, the White majority status population will become a numerical 'minority' in the future (U.S. Census Bureau, 2011). For example, a study in the UK indicated that the total ethnic minority status population in the country would make up 44 percent of the total population by 2056 (Coleman, 2010). Therefore, how children learn to navigate complex relationships in such super-diverse settings is even more critical now. At the same time, it is crucial to understand the developmental trajectory of the social skills needed to navigate this new social context, since many social skills that develop during this period are known to be influential in later stages of life (Vernberg, Abwender, Ewell, \& Beery, 1992; Welsh, Parke, Widaman, \& O’Neil, 2001).

On the one hand, multicultural societies offer a number of challenges such as perceived discrimination and intergroup anxiety which often have negative influences on the psychological, social, and academic well-being of group members (Hood, Bradley, \& Ferguson, 2017; Schmitt, Branscombe, Postmes, \& Garcia, 2014; Verkuyten, 1998). However, it is also the case that such societies provide many benefits for youth, such as the opportunity to expand their sense of self, develop empathy and perspective-taking through cross-group friendships, and learn from other cultures (Paolini, Wright, Dys-Steenbergen, \& Favara, 2016; Pettigrew \& Tropp, 2008). The current chapter will review theoretical and empirical findings from contemporary social and developmental research which highlights the unique role of multicultural societies in shaping majority and minority children's lives.

\section{Potential challenges of multicultural societies}

Imagine that you are surrounded by people from diverse backgrounds and you are the only one from your own ethnic/cultural background. You may 
not know what to expect, how to respond, and how to communicate with these people coming from a totally different cultural background than yours. Certainly, you may expect to receive some negative treatment towards yourself, even if you do not encounter any. This is the biggest challenge a lot of group members face in everyday intergroup contexts where they meet new people from other ethnic/cultural backgrounds. Hence, at first glance, a multicultural environment may provide a threatening social context where intergroup relations are difficult to initiate and maintain. Such multicultural contexts may increase the perception of discrimination and intergroup anxiety, which in turn do not only lead to more negative intergroup attitudes and behaviors, but also relate to lower psychological and academic outcomes at the individual level. This section will highlight how multicultural social contexts may potentially involve 'dangers' for minority and majority group youth.

\section{Perceived discrimination}

In multicultural societies, where social environments such as schools include a variety of ethnic/racial groups that are often visible and where group membership becomes a salient aspect of identities, children and adolescents often experience discrimination. However, increased diversity may not readily translate into a hostile social environment where discrimination is pervasive. Previous research has shown the perception of diversity to be positively associated with the perception of discrimination (Seaton \& Yip, 2008), whereas some studies suggested that minorities in desegregated settings may report lower levels of discrimination (Graham \& Juvonen, 2002; Postmes \& Branscombe, 2002; Verkuyten \& Thijs, 2002). Other research studies have shown that increased ethnic diversity has a protective role for ethnic minority youth by relating to greater levels of social satisfaction and feelings of safety (Juvonen, Nishina, \& Graham, 2006). These findings indicate that there may be a complex relationship between diversity and perceived discrimination in various multicultural settings.

Discrimination, based on any group membership such as race, ethnicity, gender, or sexual orientation, involves harmful actions towards specific group members because of their group membership (Brown, 2017). Although previous research has shown discrimination to be more common among minority status group children compared to majority status group children (e.g., Verkuyten, 2002; Verkuyten \& Thijs, 2002), pervasive discrimination may be part of the social life of majority status group members too (Coker et al., 2009). Recent research has suggested that majority status group Whites have also started to deal with 'reverse racism' which involves racism from minority status group members (Norton \& Sommers, 2011). Hence, irrespective of group status, it is important to understand 
how perceived discrimination is likely to have a detrimental effect on the well-being of all individuals.

Ethnic/racial discrimination during childhood and adolescence often involves negative treatment based on ethnic/racial group in the school or classroom environment. It includes processes such as peer victimization, social exclusion, and name calling, which are known to have adverse effects on group members' well-being in various domains (Seaton, Neblett, Cole, \& Prinstein, 2013; Simons et al., 2002; Verkuyten, 2002; Wong, Eccles, \& Sameroff, 2003). Empirical evidence demonstrates that perceived discrimination is related to lower self-esteem and psychological resilience (Bagci, Rutland, Kumashiro, Smith, \& Blumberg, 2014; Verkuyten, 1998), lower life satisfaction (Seaton, Caldwell, Sellers, \& Jackson, 2008; Verkuyten, 2008), and stress, depression, and anxiety-related symptoms (Schmitt et al., 2014). Moreover, when these discriminatory behaviors are faced in the school environment, it may also have detrimental effects on academic outcomes. Previous research revealed that there is a direct negative association between perceived discrimination and academic motivation (e.g., Verkuyten \& Thijs, 2004), and the relationship between perceived discrimination and negative school adjustment is found to be mediated by increased stress levels in the school environment (Liebkind, JasinskajaLahti, \& Solheim, 2004).

Research also suggests there are a number of moderators of the association between perceived discrimination and well-being. For example, although discrimination may occur among majority group members too in super-diverse social settings, majority group members are less likely to show the negative effects of perceived discrimination in their psychological well-being (Bagci, Rutland,Smith \& Blumberg 2014). According to Schmitt and Branscombe (2002), the implications of perceived discrimination may be different for majority and minority status group members. Majority status group members have the structural power in society and therefore perceived discrimination does not necessarily correspond to isolation and stigmatization from society, whereas for the minority status group, who have low power within society, it often means social exclusion and stigmatization from the wider population, which makes perceived discrimination more detrimental for them. Nevertheless, empirical research looking into effects of perceived discrimination among majority youth is scarce, and discrimination towards ethnic majority status youth may be as detrimental as discrimination towards ethnic minority youth where status imbalance is not that salient (such as in low socio-economic schools). Furthermore, the source of discrimination, whether it is from peers or adults, may indicate the extent to which it is detrimental for well-being (Benner \& Graham, 2013). Research suggests that discrimination is more harmful when it originates from peers, and group level discrimination rather than personal level discrimination is more prevalent among both minority and 
majority status adolescents (Verkuyten, 2002). Findings also demonstrate the importance of a positive school racial climate - a positive social atmosphere where diversity is valued - in moderating the effects of perceived discrimination on children's social and developmental outcomes (e.g., Brown, 2015).

An interesting research avenue has shown that lower self-esteem and psychological well-being may not be unconditional consequences of perceived discrimination. A number of studies indicated that perceived discrimination may influence well-being positively, as individuals are likely to attribute failure to external cues and consequently continue to maintain high levels of psychological functioning (Brown, Bigler, \& Chu, 2010; Crocker \& Major, 1989). Other research has shown that although the direct association between perceived discrimination and psychological wellbeing is negative, perceived discrimination may contribute to well-being indirectly by promoting ingroup identification. According to the Rejection-Identification Model (Branscombe, Schmitt, \& Harvey, 1999), when individuals perceive pervasive discrimination, they respond by forming a strong identity to these negative intergroup experiences. Consequently, such a strong ingroup identification process is likely to be related to higher psychological well-being (Armenta \& Hunt, 2009; Branscombe et al., 1999; Schmitt \& Branscombe, 2002). Overall, this research literature indicates that perceived discrimination is one potential risk factor for youth development, yet such negative experiences are likely to be attenuated by many individual and social factors.

\section{Intergroup anxiety}

A further challenge of multicultural societies is intergroup anxiety, which may be sometimes as detrimental as perceived discrimination among minority and majority group members. Intergroup anxiety is the 'negative feeling or affective state' derived from intergroup interactions (Levine \& Hogg, 2010, p. 465) and may be experienced through direct interaction with an outgroup member and as a result of anticipation of a future negative intergroup experience (Stephan, 2014). Previous research has suggested that the structure of the social environment may be a critical aspect of the experience of intergroup anxiety and thus multicultural settings may create stressful intergroup encounters. For example, status differences, competition, and ethnic composition have been indicated to be important in the emergence of intergroup anxiety (Avery, Richeson, Hebl, \& Ambady, 2009; Stephan, 2014), which could consequently result in a socially exclusive intergroup setting characterized by high levels of segregation and avoidance of intergroup contact.

Both majority and minority status group youth are likely to experience intergroup anxiety (e.g., Plant \& Butz, 2006; Plant \& Devine, 2003), and 
research comparing the experience of intergroup anxiety across majority and minority youth is mixed. For example, Jasinskaja-Lahti, Mähönen, and Liebkind (2011) found that although intergroup anxiety levels were higher among majority group adolescents, it was more strongly related to outgroup attitudes among minority group adolescents. Another study among native and immigrant secondary school students in Italy indicated that intergroup anxiety was equally likely to be a mediator between contact and attitudes among both groups (Vezzali, Giovannini, \& Capozza, 2010). Nevertheless, majority and minority group members may hold distinct motivations behind their intergroup anxieties (Tropp, Mazziotta, \& Wright, 2016), such that for majority group members intergroup experiences are considered to be stressful because of the fear of 'seeming prejudiced', whereas for minority group members, the real challenge is the potential of being the targets of discrimination (Devine \& Vasquez, 1998).

Other empirical research has shown that intergroup anxiety is associated with both negative cognitive and affective responses to outgroup members such as negative stereotypes and attitudes (Pettigrew \& Tropp, 2008; Stephan, Stephan, Demitrakis, Yamada, \& Clason, 2000; Stephan, Ybarra, \& Rios Morrison, 2009), as well as negative contact intentions for future interactions (Hutchison, Fox, Laas, Matharu, \& Urzi, 2010; Hutchison \& Rosenthal, 2011). Although research on children and youth's intergroup anxiety has been studied relatively less, it has been found that intergroup anxiety is associated with lower levels of self-disclosure (Turner, Hewstone, \& Voci, 2007). This suggests that intergroup anxiety may be a major obstacle in multicultural settings leading to less effective communication patterns and avoidance of further cross-ethnic interactions, consequently obstructing the formation of an inclusive social setting.

Beyond its detrimental effects on outgroup attitudes and behaviors, intergroup anxiety is likely to reduce psychological and academic wellbeing of individuals. For example, Mendoza-Denton, Downey, Purdie, Davis, and Pietrzak (2002) demonstrated that race-based rejection sensitivity - 'a cognitive-affective processing dynamic whereby people anxiously expect, readily perceive, and intensely react to rejection in situations in which rejection is possible' (p. 897) - was related to lower levels of belongingness and academic grades among African American university students. Hence, negative expectations and the anticipation of rejection is likely to undermine motivational outcomes, as well as psychological ones (e.g., Reis \& Downey, 1999).

A related construct, stereotype threat, is also a common phenomenon, especially in multicultural school settings where group membership may be a salient aspect of school experiences. Stereotype threat, that is, perceived threat based on the knowledge that one is evaluated negatively on the basis of his/her group membership, is known to be related to lower levels of performance on a related task (Steele \& Aronson, 1995). The 
construct has been consistently observed among various groups, such as African Americans performing poorly on academic ability tasks and women performing poorly on mathematical tasks (e.g., Spencer, Steele, \& Quinn, 1999; Steele \& Aronson, 1995). This shows that anxieties that may stem from the anticipation of future intergroup contact or just the mere recognition that one is compared to other groups may evoke negative feelings and create a stressful environment for certain group members, which may eventually reflect on group members' psychological and academic well-being.

\section{Potential benefits of multicultural societies}

Multicultural societies are difficult, but they do not only offer challenging experiences for children and youth: they also offer constructive opportunities for positive psychological and social development. Previous research has provided consistent evidence of children and youth's preference for same-ethnic interactions (Aboud \& Mendelson, 1996; McPherson, SmithLovin, \& Cook, 2001) and shown that cross-ethnic relationships are difficult to initiate, maintain, and become even less common during transition through adolescence (Aboud, Mendelson, \& Purdy, 2003; Jugert, Noack, \& Rutland, 2011; Kao \& Joyner, 2004). Although ethnic diversity increases the chances that one forms more cross-ethnic interactions (Bagci, Kumashiro, Smith, Blumberg, \& Rutland, 2014; Quillian \& Campbell, 2003), many children are still inclined to choose others with whom they share similarities and common experiences, perhaps because ingroup members provide a more secure environment. Nevertheless, children do engage in positive cross-ethnic interactions in multicultural settings and form friendships that cross ethnic boundaries (Bagci, Kumashiro, Smith \& Rutland 2014), and once they are formed, research suggest that cross-ethnic friendships are the best means available to create a socially integrative intergroup context.

\section{Intergroup contact and cross-group friendships}

One of the positive features of multicultural societies is that they provide plenty of opportunities to form intergroup relationships. Intergroup contact theory (Allport, 1954; Pettigrew, 1998) suggested that contact between members of different groups is able to reduce prejudice and promote positive intergroup attitudes and behaviors. Empirical research has consistently shown that children's intergroup contact experiences are related to more positive evaluations of the outgroup across different intergroup contexts (see Tropp \& Prenovost, 2008). Schools are probably the most convenient social settings to provide such opportunities (Thijs \& Verkuyten, 2014; Titzmann, 2014), especially since they encompass many of 
the contact conditions initially suggested by Allport, including equal status and a cooperative learning environment. Nevertheless, ethnically diverse classrooms may not readily promote integration at the societal level and the potential benefits of multicultural settings may only appear under certain conditions.

Previous research has shown that, like ethnic diversity, intergroup contact per se may not be strong enough to directly change intergroup attitudes (Dovidio, Gaertner, \& Kawakami, 2003), although contact has been found to relate to more positive attitudes, even in the absence of positive contact conditions initially proposed by Allport (Pettigrew \& Tropp, 2006). Therefore, rather than superficial intergroup encounters that fade away instantly, an established, positive, and reliable cross-ethnic interaction pattern would have stronger effects on intergroup relationships. Pettigrew (1998) suggested that cross-group friendships are of particular importance in changing intergroup relationships, since (a) they involve Allport's contact conditions, (b) they are long-term and stable, (c) they are reciprocated, and (d) they include positivity and intimacy, as well as trust, self-disclosure, and support (e.g., Pettigrew, Tropp, Wagner, \& Christ, 2011). Empirical evidence also highlighted the special role assigned to cross-group friendship potential in contact literature (see Pettigrew \& Tropp, 2006). Therefore, many research studies have recently started to concentrate on the specific role of cross-group friendships among children and youth, rather than mere intergroup contact.

A further promising finding is that cross-group friendships are supposed to be effective in promoting intergroup relationships for both majority and minority status group children and adolescents, although contact effects among minority group members are usually relatively weaker (Pettigrew \& Tropp, 2006; Tropp \& Pettigrew, 2005). Some studies did not observe specific differences across status as regards the effects of intergroup contact on race-based exclusionary behaviors (Crystal, Killen, \& Ruck, 2008). For example, in a sample of majority and minority youth in Finland, Jasinskaja-Lahti et al. (2011) found that pleasant personal contact experiences, accompanied with positive ingroup norms, were effective in encouraging positive outgroup attitudes among minority as well as majority youth. Other research has shown that cross-ethnic friendships were more effective in improving outgroup evaluations among majority group children, compared to minority status group children (Feddes, Noack, \& Rutland, 2009), overall suggesting group status as a potential moderator of crossgroup friendships' effects on outgroup attitudes.

\section{Perspective-taking, self-disclosure, and self-expansion}

Previous research has distinguished a number of ways through which intergroup contact, in particular cross-ethnic friendships, may promote social 
integration. While initial studies suggested cognitive mechanisms such as learning from the outgroup as a potential explanatory factor between crossgroup friendships and positive outgroup attitudes, more recent research has focused on the affective mediators of intergroup contact (Pettigrew \& Tropp, 2008). For example, in a study examining relationships between Asian and White children in the UK, Turner et al. (2007) found that both majority (White) and minority (Asian) status children with crossgroup friendships displayed more positive intergroup attitudes. The authors further discovered that cross-group friendships were effective in promoting positive outgroup attitudes through the generation of various interpersonal processes such as self-disclosure. Self-disclosure may be particularly important in the context of intergroup relationships during early adolescence when children start to turn away from their parents and build closer relationships with their peers who now constitute a more important source of self-worth and comfort for them (Fuligni \& Eccles, 1993).

Self-disclosure is also critical in cross-ethnic interactions, since it paves the way to the formation of deeper interpersonal processes such as increased empathy and perspective-taking towards the outgroup (Tam, Hewstone, Harwood, Voci, \& Kenworthy, 2006). Previous research has shown that cross-group friendships are likely to promote perspectivetaking and empathy, and in turn, increased empathy towards the outgroup should promote positive outgroup attitudes and relationships (Pettigrew \& Tropp, 2008). Furthermore, cross-group friendships may support the development of more tolerant attitudes among children and adolescents by providing cultural openness (Abbott \& Cameron, 2014) and increasing the perceived value of diversity (Tropp \& Bianchi, 2006). Intergroup contact and friendships have been also found to be related to the adoption of more tolerant attitudes such as multiculturalism. Accordingly, contact and cross-group friendships lead to the reappraisal of the ingroup whereby individuals get more distant to their ingroup and eventually display a less egocentric and more open view of the world (Deprovincialization Hypothesis, Pettigrew, 1997). Since contact effects do not only concern attitudes and behaviors towards the target outgroup, but often generalize to attitudes towards other groups (even non-contacted) in different contexts, in the long-term, cross-ethnic friendships during childhood and adolescence may lead to the development of important perspective-taking and empathic skills that are transformed into a more open and understanding view of the world in adulthood.

Another process that may emerge as a result of self-disclosure is inclusion of the other in the self (IoS)'. Cross-group friendships are likely to foster interpersonal processes between the self and a partner from an outgroup; as a result, children may become more interested in expanding the self and use cross-ethnic relationships as an opportunity to self-expand (Aron, McLaughlin-Volpe, Mashek, Lewandowski, Wright, \& Aron, 2004; 
Cameron, Rutland, Brown, \& Douch, 2006). According to the SelfExpansion Model (Aron \& Aron, 1986), individuals have a strong desire to get close to others in order to expand and improve their own self. This need is further characterized by the desire to approach the ones who are dissimilar to us, as a way to gain access to resources that may not be provided by the ones who are similar to us (Paolini et al., 2016). Therefore, against all findings in the friendship literature emphasizing the role of homophily in friendship choices, humans may be more motivated to be attracted to the ones who are different, as a way to contribute to the self. Cross-ethnic friendships, therefore, unlike same-ethnic friendships, are important tools to satisfy this need for self-expansion, providing access to various resources which may be inaccessible without interethnic contact.

Self-disclosure may further enhance other interpersonal mechanisms such as affirmation of ideal-selves - the extent to which cross-ethnic friends are perceived as eliciting the child's ideal self (Bagci, Kumashiro, Rutland, Smith, \& Blumberg, 2017). Previous research into interpersonal relationships literature demonstrates that close others are likely to shape one's motivations and aspirations through affirming the ideal-self (i.e., close others supporting the sense an individual has of the ideal person they wish to become), and such a process, in turn, is related to closer relationships and better personal well-being (Michelangelo Phenomenon, Rusbult, Finkel, \& Kumashiro, 2009). In a multicultural society, when children's self-esteem declines during early adolescence (Wigfield, Eccles, Mac Iver, Reuman, \& Midgley, 1991), affirmation of the ideal-self, especially when it originates from cross-ethnic peers, would be likely to provide outgroup support, encouragement, and opportunity to expand the self in new and desirable directions. This is a critical mechanism that reduces negative expectations from the outgroup and contributes to positive developmental outcomes. Indeed, Bagci et al. (2017) found that for both minority and majority status children recruited from super-diverse London schools, cross-ethnic friendships promoted academic and psychological well-being through increased affirmation of the ideal-self.

\section{Psycho-social benefits of cross-group friendships}

Beyond the benefits of cross-group friendships in promoting positive intergroup attitudes through the generation of self-related interpersonal processes, recent research has started to focus on whether children's crossethnic friendships in multicultural settings are beneficial for the enhancement of positive social and psychological outcomes. Apart from empathic skills children gain through close cross-ethnic friendships, such friendships do also provide various unique benefits that may not be obtained through same-ethnic friendships. For example, Lease and Blake (2005) found that cross-group friendships are related to increased social 
competence and popularity. Kawabata and Crick (2008) further indicated that cross-ethnic friendships, but not same-ethnic friendships, were related to social adjustment, assessed by the level of relational inclusion and leadership. This shows that beyond the generation of particular skills such as perspective-taking and empathy, children with cross-ethnic friends are viewed as more skilled and competent than their peers with no such friendships.

Another line of research has indicated that friendships that cross ethnic boundaries are also associated with psychological outcomes among children and youth. For example, Munniksma and Juvonen (2012) studied the role of cross-ethnic friendships on feelings of socio-emotional safety among Latino and White American sixth and seventh grade children attending multiethnic schools, and found that over time children who had more cross-ethnic friends felt safer in the school environment. In a similar vein, Kawabata and Crick (2011) demonstrated that such friendships were able to decrease potential relational victimization among elemantary school children. A further study by Graham, Munniksma, and Juvonen (2014) also showed that cross-ethnic friendships were associated with decreases in perceived vulnerability. This suggests that cross-ethnic friendships may indicate that such children live in a predictable, stable, and thereby safe social environment where the potential dark side of multicultural societies is felt to a lesser degree.

Cross-ethnic friendships do not only have strong direct association with positive developmental outcomes, but they could also function as effective protective mechanisms that could potentially buffer the negative effects of various risk factors in a challenging multiethnic environment. In a study of ethnic minority children, Bagci, Rutland,Smith \& Blumberg (2014) investigated whether cross-ethnic friendship quantity and quality would directly increase psychological well-being and resilience and attenuate the negative effects of perceived discrimination on well-being. Findings indicated that cross-ethnic friendships did not only directly relate to both positive developmental outcomes, but they also buffered the negative effects of perceived discrimination on mental health such that the detrimental effects of perceived discrimination emerged only among minority children with lower cross-ethnic friendship quantity.

While these studies in principle show that multicultural settings offer both challenges and benefits, and cross-ethnic friendships may stand as important resources of resilience against these real life challenges, recent research has indicated that they may not unconditionally provide benefits for group members as regards more positive outgroup attitudes, for example if the social context is highly conflictual (Bagci \& Çelebi, 2017) or when the quality of cross-ethnic friendships is low (Cernat, 2018). Moreover, in a recent study by Brenick, Schachner, and Jugert (2018), minority youth's friendships with majority group members exacerbated the 
negative role of perceived discrimination on well-being; this effect was pronounced less among the ones who perceived a more positive racial climate. Overall, this suggests that the benefits of cross-group friendships may also depend on various factors such as the specific intergroup context involved and the quality of relationships.

\section{Confidence in contact model and cross-ethnic friendship self-efficacy}

Based on past research highlighting the benefits of cross-group friendships in multiethnic settings, it is critical to explore how and when healthy (i.e., close, positive, stable) cross-ethnic friendships are formed. Previous research has mainly concentrated on opportunities for contact vs. homophily tendencies as preliminary factors behind cross-ethnic friendship formation (McPherson et al., 2001; Quillian \& Campbell, 2003; Titzmann, 2014), while other research has focused on specific individual factors such as outgroup orientation and/or environmental factors such as peer norms and perceived contact conditions (Jugert et al., 2011; Tropp, O’Brien, \& Migacheva, 2014). Recently, Turner and Cameron (2016) developed an inclusive theoretical model in which children may become 'contact ready' through various situational and contextual factors. The authors suggested that although structural factors such as ethnic diversity is a prerequisite for the formation of cross-group friendships, diversity alone may not necessarily lead to more positive outcomes among children (Brown et al., 2013) and the benefits of multicultural social settings may be only provided if the setting encourages the formation of more stable and positive crossgroup friendships. Accordingly, it was suggested that for the promotion of cross-group friendships, children should first acquire confidence in contact, which is described as a state of readiness to engage in successful crossgroup friendships (Turner \& Cameron, 2016). The authors further proposed a number of situational and individual factors in fostering confidence in contact, including a positive school setting, reduced intergroup anxiety, more positive initial outgroup attitudes and social skills such as empathy and perspective-taking abilities. Such a high level of confidence in contact, in turn, should lead to more benefits from diversity at the intergroup and personal level.

Further empirical research has provided initial evidence for the Confidence in Contact Model. Bagci, Cameron, Turner, Morais, Carby, Ndhlovu, \& Leney (forthcoming) introduced a new concept, 'cross-ethnic friendship self-efficacy', by integrating the cross-group friendship literature with Bandura's Self-Efficacy Theory (1986). Accordingly, the formation and maintenance of cross-ethnic friendships in multiethnic settings is contingent upon children's self-efficacy beliefs in forming and maintaining successful cross-ethnic friendships. The original self-efficacy 
theory assumes that the most critical factor behind performing a specific behavior/action is how much the individual believes he/she can succeed in this behavior/action (Bandura, 1986). Hence, it could be expected that children who actually believe that they could initiate and maintain cross-group friendships would be more likely to engage in actual crossethnic friendships.

The authors further investigated the sources of these self-efficacy beliefs and suggested a model in which previously distinguished factors in crossgroup friendship formation are integrated. The original Self-Efficacy Theory stated that the most important antecedent of self-efficacy beliefs is past accomplishment (enactive experiences). Accordingly, self-efficacy beliefs about cross-ethnic friendships should be based on whether children had experienced successful interethnic experiences in the past. This has been confirmed in the contact literature showing cross-group friendship habits in childhood are reflected in later stages of life (Stearns, Buchmann, \& Bonneau, 2009). A second potential source of self-efficacy beliefs is vicarious experiences; observing other people to successfully perform a behavior increases the belief that one can also succeed in a similar behavior. This corresponds to vicarious and extended cross-group friendships which are likely to promote the formation of direct cross-group friendships (Cameron et al., 2006; Feddes et al., 2009; Turner et al., 2007; Wright, Aron, Mclaughlin-Volpe, \& Ropp, 1997). A third source of self-efficacy beliefs from the original theory is social (verbal) persuasion, which highlights the importance of parents and peers in encouraging cross-ethnic friendship formation (e.g., Crystal et al., 2008). A final source of selfefficacy beliefs is physiological states which include negative emotional reactions to intergroup contact such as intergroup anxiety and stress. This has been specifically highlighted in the cross-group friendship literature by consistent empirical findings about the negative role of intergroup anxiety in the formation of cross-ethnic interactions (Page-Gould, MendozaDenton, \& Tropp, 2008).

Overall, across two studies, Bagci et al. (accepted manuscript) found that cross-ethnic friendship self-efficacy was predicted by all sources of self-efficacy beliefs (except social norms) and in turn self-efficacy was related to greater quality cross-ethnic friendships. Study 2 further incorporated perceived parental quality into this model and demonstrated parental cross-ethnic contact as a further antecedent of children's cross-ethnic friendship self-efficacy (Bagci, Cameron, Turner, Morais, Ndhlovu, \& Leney, under review). This shows that, as in Turner and Cameron's (2016) Confidence in Contact Model, cross-ethnic friendships are not just a natural consequence of ethnic diversity; rather they emerge and exist as a function of various complex situational and personal factors in the process. Figure 11.1 depicts the theoretical model of cross-ethnic friendship self-efficacy. 


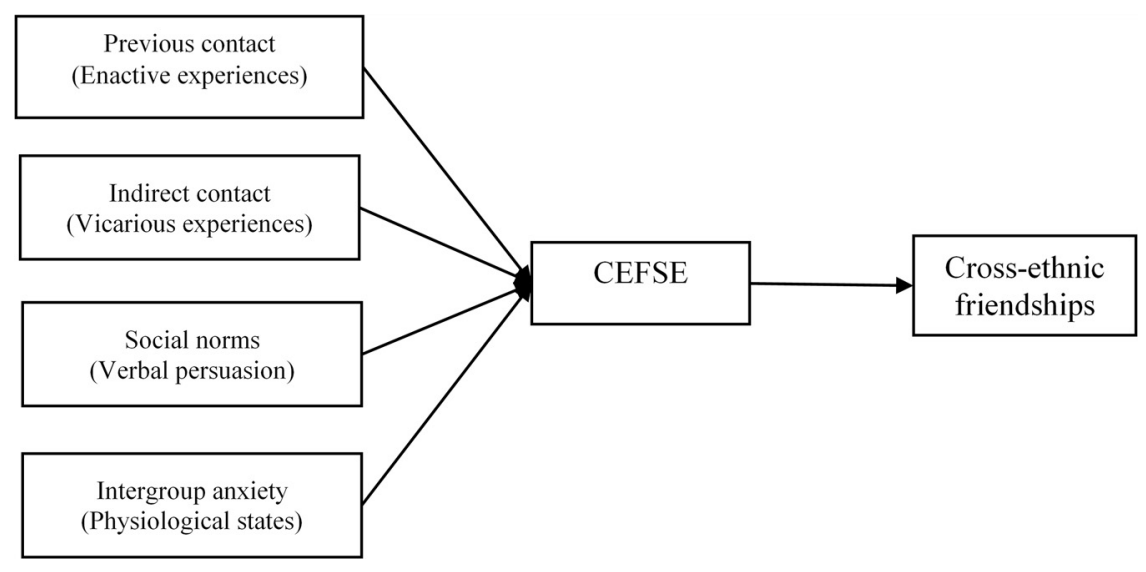

Figure I I.I Cross-Ethnic Friendship Self-Efficacy Model

CEFSE $=$ cross-ethnic friendship self-efficacy.

\section{Conclusion}

Ethnic diversity may not unconditionally provide positive or negative socialdevelopmental outcomes for children and youth. Living in multicultural societies may result in a range of developmental outcomes which are contingent upon whether children transform these characteristics into opportunities or challenges. Such a transformation depends on the combination of a number of personal, situational, and structural processes involved in the setting. Therefore, while ethnic diversity may create an anxiety-provoking and exclusive setting where children and youth experience challenges in the social context, it can also create a unique, positive, and inclusive interethnic environment that could boost children's personal, interpersonal, and social well-being. Under the latter setting, children and youth would be more likely to enjoy schooling experiences and fully benefit from the resources provided by a multicultural setting. Cross-group friendships constitute one potential resource children can rely on, providing unique social skills, such as self-disclosure, empathy, and self-expansion, and enabling children to feel a sense of belonging and safety in a potentially threatening social setting. A number of individual and situational factors are required for the facilitation of cross-group friendships. Importantly, school and family settings are responsible for encouraging a positive and inclusive intergroup setting and cultivating self-efficacy beliefs in children towards forming cross-group friendships, which should eventually equip children with the unique and necessary skills and resources to navigate and succeed in a multicultural society. 


\section{References}

Abbott, N., \& Cameron, L. (2014). What makes a young assertive bystander? The effect of intergroup contact, empathy, cultural openness, and in-group bias on assertive bystander intervention intentions. Journal of Social Issues, 70, 167-182.

Aboud, F. E., \& Mendelson, M. J. (1996). Determinants of friendship selection and quality: Developmental perspectives. In W. M. Bukowski, A. F. Newcomb, \& W. W. Hartup (Eds.), Cambridge studies in social and emotional development. The company they keep: Friendship in childhood and adolescence (pp. 87-112). New York, NY: Cambridge University Press.

Aboud, F. E., Mendelson, M. J., \& Purdy, K. T. (2003). Cross-race peer relations and friendship quality. International Journal of Behavioral Development, 27, 165-173.

Allport, G. W. (1954). The nature of prejudice. New York, NY: Addison-Wesley.

Armenta, B. E., \& Hunt, J. S. (2009). Responding to societal devaluation: Effects of perceived personal and group discrimination on the ethnic group identification and personal self-esteem of Latino/Latina adolescents. Group Processes \& Intergroup Relations, 12(1), 23-39.

Aron, A., \& Aron, E. (1986). Love and the expansion of self: Understanding attraction and satisfaction. New York: Hemisphere.

Aron, A., McLaughlin-Volpe, T., Mashek, D., Lewandowski, G., Wright, S. C., \& Aron, E. N. (2004). Including others in the self. European review of social psychology, 15(1), 101-132.

Avery, D. R., Richeson, J. A., Hebl, M. R., \& Ambady, N. (2009). It does not have to be uncomfortable: The role of behavioral scripts in Black-White interracial interactions. Journal of Applied Psychology, 94, 1382-1393.

Bagci, S. C., \& Çelebi, E. (2017). Cross-group friendships and outgroup attitudes among Turkish-Kurdish ethnic groups: Does perceived interethnic conflict moderate the friendship-attitude link? Journal of Applied Social Psychology, 47, 59-73.

Bagci, S. C., Kumashiro, M., Rutland, A., Smith, P. K., \& Blumberg, H. (2017). Cross-ethnic friendships, psychological well-being, and academic outcomes: Study of south asian and white children in the UK. European Journal of Developmental Psychology, 14, 190-205.

Bagci, S. C., Kumashiro, M., Smith, P. K., Blumberg, H., \& Rutland, A. (2014). Cross-ethnic friendships: Are they really rare? Evidence from secondary schools around London. International Journal of Intercultural Relations, 41, 125-137.

Bagci, S. C., Rutland, A., Kumashiro, M., Smith, P. K., \& Blumberg, H. (2014). Are minority status childrens cross-ethnic friendships beneficial in a multiethnic context? British Journal of Developmental Psychology, 32, 107-115.

Bagci, S. C., Cameron, L., Turner, R., Morais, C., Carby, A., Ndhlovu, M., \& Leney, A. (forthcoming). 'Cross-ethnic friendship self-efficacy': A new predictor of cross-ethnic friendships among children. Group Processes and Intergroup Relations.

Bandura, A. (1986). Fearful expectations and avoidant actions as coeffects of perceived self-inefficacy. American Psychologist, 41, 1389-1391.

Benner, A. D., \& Graham, S. (2013). The antecedents and consequences of racial/ ethnic discrimination during adolescence: Does the source of discrimination matter? Developmental Psychology, 49, 1602-1613. 
Branscombe, N. R., Schmitt, M. T., \& Harvey, R. D. (1999). Perceiving pervasive discrimination among African Americans: Implications for group identification and well-being. Journal of Personality and Social Psychology, 77, 135-149.

Brenick, A., Schachner, M. K., \& Jugert, P. (2018). Help or hindrance? Minority versus majority cross-ethnic friendships altering discrimination experiences. Journal of Applied Developmental Psychology, 59, 26-35.

Brown, C. S. (2015). The educational, psychological, and social impact of discrimination on the immigrant child. Washington, DC: Migration Policy Institute.

Brown, C. S., Bigler, R. S., \& Chu, H. (2010). An experimental study of the correlates and consequences of perceiving oneself to be the target of gender discrimination. Journal of Experimental Child Psychology, 107, 100-117.

Brown, R., Baysu, G., Cameron, L., Nigbur, D., Rutland, A., Watters, C., Hossain, R., LeTouze, D., \& Landau, A. (2013). Acculturation attitudes and social adjustment in British South Asian children: a longitudinal study. Personality and Social Psychology Bulletin, 39(2), 1656-1667.

Brown, J. (2017). Discriminatory experiences of women police. A comparison of officers serving in England and Wales, Scotland, Northern Ireland and the Republic of Ireland. International Journal of the Sociology of Law, 28, 91-111.

Cameron, L., Rutland, A., Brown, R., \& Douch, R. (2006). Changing childrens intergroup attitudes toward refugees: Testing different models of extended contact. Child Development, 77, 1208-1219.

Cernat, V. (2018). When cross-ethnic friendships can be bad for out-group attitudes: The importance of friendship quality. Journal of Community $\&$ Applied Social Psychology, 29(2), 81-89.

Coker, T. R., Elliott, M. N., Kanouse, D. E., Grunbaum, J. A., Schwebel, D. C., Gilliland, M. J., \& Schuster, M. A. (2009). Perceived racial/ethnic discrimination among fifth-grade students and its association with mental health. American Journal of Public Health, 99, 878-884.

Coleman, D. (2010). Projections of the ethnic minority populations of the United Kingdom 2006-2056. Population and Development Review, 36, 441-486.

Crocker, J., \& Major, B. (1989). Social stigma and self-esteem: The self-protective properties of stigma. Psychological Review, 96, 608-630.

Crystal, D. S., Killen, M., \& Ruck, M. (2008). It is who you know that counts: Intergroup contact and judgments about race-based exclusion. British Journal of Developmental Psychology, 26, 51-70.

Devine, P. G., \& Vasquez, K. A. (1998). The rocky road to positive intergroup relations. In J. Eberhardt \& S. T. Fiske (Eds.), Confronting racism: The problem and the response (pp. 234-262). Newbury Park, CA: Sage.

Dovidio, J. F., Gaertner, S. L., \& Kawakami, K. (2003). Intergroup contact: The past, present, and the future. Group Processes E Intergroup Relations, 6, 5-21.

Feddes, A. R., Noack, P., \& Rutland, A. (2009). Direct and extended friendship effects on minority and majority children's interethnic attitudes: A longitudinal study. Child Development, 80, 377-390.

Fuligni, A. J., \& Eccles, J. S. (1993). Perceived parent-child relationships and early adolescents orientation toward peers. Developmental Psychology, 29, 622-632.

Graham, S., \& Juvonen, J. (2002). Ethnicity, peer harassment, and adjustment in middle school, The Journal of Early Adolescence, 22, 173-199. 
Graham, S., Munniksma, A., \& Juvonen, J. (2014). Psychosocial benefits of crossethnic friendships in urban middle schools. Child Development, 85, 469-483.

Hood, W., Bradley, G. L., \& Ferguson, S. (2017). Mediated effects of perceived discrimination on adolescent academic achievement: A test of four models. Journal of Adolescence, 54, 82-93.

Hutchison, P., Fox, E., Laas, A. M., Matharu, J., \& Urzi, S. (2010). Anxiety, outcome expectancies, and young peoples willingness to engage in contact with the elderly. Educational Gerontology, 36, 1008-1021.

Hutchison, P., \& Rosenthal, H. E. (2011). Prejudice against Muslims: Anxiety as a mediator between intergroup contact and attitudes, perceived group variability and behavioural intentions. Ethnic and Racial Studies, 34, 40-61.

Jasinskaja-Lahti, I., Mähönen, T. A., \& Liebkind, K. (2011). Ingroup norms, intergroup contact and intergroup anxiety as predictors of the outgroup attitudes of majority and minority youth. International Journal of Intercultural Relations, $35,346-355$.

Jugert, P., Noack, P., \& Rutland, A. (2011). Friendship preferences among German and Turkish preadolescents. Child Development, 82, 812-829.

Juvonen, J., Nishina, A., \& Graham, S. (2006). Ethnic diversity and perceptions of safety in urban middle schools. Psychological Science, 17, 393-400.

Kao, G., \& Joyner, K. (2004). Do race and ethnicity matter among friends? Activities among interracial, interethnic, and intraethnic adolescent friends. The Sociological Quarterly, 45, 557-573.

Kawabata, Y., \& Crick, N. R. (2008). The role of cross-racial/ethnic friendships in social adjustment. Developmental Psychology, 44, 1177-1183.

Kawabata, Y., \& Crick, N. R. (2011). The significance of cross-racial/ethnic friendships: Associations with peer victimization, peer support, sociometric status, and classroom diversity. Developmental Psychology, 47, 1763-1775.

Lease, A. M., \& Blake, J. J. (2005). A comparison of majority-race children with and without a minority-race friend. Social Development, 14, 20-41.

Levine, J. M., \& Hogg, M. A. (2010). Encyclopedia of group processes and intergroup relations (Vol. 1). Thousand Oaks, CA: Sage.

Liebkind, K., Jasinskaja-Lahti, I., \& Solheim, E. (2004). Cultural identity, perceived discrimination, and parental support as determinants of immigrants' school adjustments. Journal of Adolescent Research, 19, 635-656.

McPherson, M., Smith-Lovin, L., \& Cook, J. M. (2001). Birds of a feather: Homophily in social networks. Annual Review of Sociology, 27, 415-444.

Mendoza-Denton, R., Downey, G., Purdie, V. J., Davis, A., \& Pietrzak, J. (2002). Sensitivity to status-based rejection: Implications for African American students college experience. Journal of Personality and Social Psychology, 83, 896-918.

Munniksma, A., \& Juvonen, J. (2012). Cross-ethnic friendships and sense of social-emotional safety in a multiethnic middle school: An exploratory study. Merrill-Palmer Quarterly, 58, 489-506.

Norton, M. I., \& Sommers, S. R. (2011). Whites see racism as a zero-sum game that they are now losing. Perspectives on Psychological Science, 6, 215-218.

Page-Gould, E., Mendoza-Denton, R., \& Tropp, L. R. (2008). With a little help from my cross-group friend: Reducing anxiety in intergroup contexts through cross-group friendship. Journal of Personality and Social Psychology, 95, 1080-1094. 
Paolini, S., Wright, S. C., Dys-Steenbergen, O., \& Favara, I. (2016). Self-expansion and intergroup contact: Expectancies and motives to self-expand lead to greater interest in outgroup contact and more positive intergroup relations. Journal of Social Issues, 72, 450-471.

Pettigrew, T. F. (1997). Generalized intergroup contact effects on prejudice. Personality and Social Psychology Bulletin, 23, 173-185.

Pettigrew, T. F. (1998). Intergroup contact theory. Annual Review of Psychology, 49, 65-85.

Pettigrew, T. F., \& Tropp, L. R. (2006). A meta-analytic test of intergroup contact theory. Journal of Personality and Social Psychology, 90, 751-783.

Pettigrew, T. F., \& Tropp, L. R. (2008). How does intergroup contact reduce prejudice? Meta-analytic tests of three mediators. European Journal of Social Psychology, 38, 922-934.

Pettigrew, T. F., Tropp, L. R., Wagner, U., \& Christ, O. (2011). Recent advances in intergroup contact theory. International Journal of Intercultural Relations, 35, 271-280.

Plant, E. A., \& Butz, D. A. (2006). The causes and consequences of an avoidance-focus for interracial interactions. Personality and Social Psychology Bulletin, 32, 833-846.

Plant, E. A., \& Devine, P. G. (2003). The antecedents and implications of interracial anxiety. Personality and Social Psychology Bulletin, 29, 790-801.

Postmes, T., \& Branscombe, N. R. (2002). Influence of long-term racial environmental context on subjective well-being in African Americans. Journal of Personality and Social Psychology, 83, 735-751.

Quillian, L., \& Campbell, M. E. (2003). Beyond Black and White: The present and future of multiracial friendship segregation. American Sociological Review, 68, 540-566.

Reis, H. T., \& Downey, G. (1999). Social cognition in relationships: Building essential bridges between two literatures. Social Cognition, 17, 97-117.

Rusbult, C. E., Finkel, E. J., \& Kumashiro, M. (2009). The Michelangelo phenomenon. Current Directions in Psychological Science, 18, 305-309.

Schmitt, M. T., \& Branscombe, N. R. (2002). The meaning and consequences of perceived discrimination in disadvantaged and privileged social groups. European Review of Social Psychology, 12, 167-199.

Schmitt, M. T., Branscombe, N. R., Postmes, T., \& Garcia, A. (2014). The consequences of perceived discrimination for psychological well-being: A meta-analytic review. Psychological Bulletin, 140, 921-948.

Seaton, E. K., Caldwell, C. H., Sellers, R. M., \& Jackson, J. S. (2008). The prevalence of perceived discrimination among African American and Caribbean Black youth. Developmental Psychology, 44, 1288-1297.

Seaton, E. K., Neblett, E. W., Cole, D. J., \& Prinstein, M. J. (2013). Perceived discrimination and peer victimization among African American and Latino youth. Journal of Youth and Adolescence, 42, 342-350.

Seaton, E. K., \& Yip, T. (2008). School and neighborhood contexts, perceptions of racial discrimination, and psychological well-being among African American adolescents. Journal of Youth and Adolescence, 38, 153-163. 
Simons, R. L., Murry, V., Mcloyd, V., Lin, K., Cutrona, C., \& Conger, R. D. (2002). Discrimination, crime, ethnic identity, and parenting as correlates of depressive symptoms among African American children: A multilevel analysis. Development and Psychopathology, 14, 371-393.

Spencer, S. J., Steele, C. M., \& Quinn, D. M. (1999). Stereotype threat and womens math performance. Journal of Experimental Social Psychology, 35, 4-28.

Stearns, E., Buchmann, C., \& Bonneau, K. (2009). Interracial friendships in the transition to college: Do birds of a feather flock together once they leave the nest? Sociology of Education, 82, 173-195.

Steele, C. M., \& Aronson, J. (1995). Stereotype threat and the intellectual test performance of African Americans. Journal of Personality and Social Psychology, 69, 797-811.

Stephan, C. W., Stephan, W. G., Demitrakis, K. M., Yamada, A. M., \& Clason, D. L. (2000). Womens attitudes toward men: An integrated threat theory approach. Psychology of Women Quarterly, 24, 63-73.

Stephan, W. G. (2014). Intergroup anxiety: Theory, research, and practice. Personality and Social Psychology Review, 18, 239-255.

Stephan, W. G., Ybarra, O., \& Rios Morrison, K. (2009). Intergroup threat theory. In T. D. Nelson (Ed.), Handbook of prejudice (pp. 43-59). Mahwah, NJ: Lawrence erlbaum Associates.

Tam, T., Hewstone, M., Harwood, J., Voci, A., \& Kenworthy, J. (2006). Intergroup contact and grandparent-Grandchild communication: The effects of selfdisclosure on implicit and explicit biases against older people. Group Processes $\mathcal{E}$ Intergroup Relations, 9, 413-429.

Thijs, J., \& Verkuyten, M. (2014). School ethnic diversity and students interethnic relations. British Journal of Educational Psychology, 84, 1-21.

Titzmann, P. F. (2014). Immigrant adolescents adaptation to a new context: Ethnic friendship homophily and its predictors. Child Development Perspectives, 8, 107-112.

Tropp, L. R., \& Bianchi, R. A. (2006). Valuing diversity and interest in intergroup contact. Journal of Social Issues, 62, 533-551.

Tropp, L. R., Mazziotta, A., \& Wright, S. C. (2016). Recent developments in intergroup contact research: Affective processes, group status, and contact valence. In C. Sibley \& F. K. Barlow (Eds), Cambridge handbook of the psychology of prejudice (pp. 463-481). Cambridge, UK: Cambridge University Press.

Tropp, L. R., O'Brien, T. C., \& Migacheva, K. (2014). How peer norms of inclusion and exclusion predict childrens interest in cross-ethnic friendships. Journal of Social Issues, 70, 151-166.

Tropp, L. R., \& Pettigrew, T. F. (2005). Relationships between intergroup contact and prejudice among minority and majority status groups. Psychological Science, 16, 951-957.

Tropp, L. R., \& Prenovost, M. A. (2008). The role of intergroup contact in predicting children's interethnic attitudes: Evidence from meta-analytic and field studies. In S. R. Levy \& M. Killen (Eds.), Intergroup attitudes and relations in childhood through adulthood (pp. 236-248). New York, NY: Oxford University Press.

Turner, R. N., \& Cameron, L. (2016). Confidence in contact: A new perspective on promoting cross-group friendship among children and adolescents. Social Issues and Policy Review, 10, 212-246. 
Turner, R. N., Hewstone, M., \& Voci, A. (2007). Reducing explicit and implicit outgroup prejudice via direct and extended contact: The mediating role of self-disclosure and intergroup anxiety. Journal of Personality and Social Psychology, 93, 369-388.

US Census Bureau. (2011, August 01). Statistical abstract of the United States: 2012. Retrieved from www.census.gov/library/publications/2011/compendia/ statab/131ed.html

Verkuyten, M. (1998). Perceived discrimination and self-esteem among ethnic minority adolescents. The Journal of Social Psychology, 138, 479-493.

Verkuyten, M. (2002). Ethnic attitudes among minority and majority children: The role of ethnic identification, peer group victimization and parents. Social Development, 11, 558-570.

Verkuyten, M. (2008). Life Satisfaction among ethnic minorities: The role of discrimination and group identification. Social Indicators Research, 89, 391-404.

Verkuyten, M., \& Thijs, J. (2002). Racist victimization among children in The Netherlands: The effect of ethnic group and school. Ethnic and Racial Studies, 25, 310-331.

Verkuyten, M., \& Thijs, J. (2004). Psychological disidentification with the academic domain among ethnic minority adolescents in The Netherlands. British Journal of Educational Psychology, 74, 109-125.

Vernberg, E. M., Abwender, D. A., Ewell, K. K., \& Beery, S. H. (1992). Social anxiety and peer relationships in early adolescence: A prospective analysis. Journal of Clinical Child Psychology, 21, 189-196.

Vezzali, L., Giovannini, D., \& Capozza, D. (2010). Longitudinal effects of contact on intergroup relations: The role of majority and minority group membership and intergroup emotions. Journal of Community E Applied Social Psychology, 20, 462-479.

Welsh, M., Parke, R. D., Widaman, K., \& O’Neil, R. (2001). Linkages between childrens social and academic competence. Journal of School Psychology, 39, 463-482.

Wigfield, A., Eccles, J. S., Mac Iver, D., Reuman, D. A., \& Midgley, C. (1991). Transitions during early adolescence: Changes in children's domain-specific selfperceptions and general self-esteem across the transition to junior high school. Developmental Psychology, 27, 552-565.

Wong, C. A., Eccles, J. S., \& Sameroff, A. (2003). The influence of ethnic discrimination and ethnic identification on African American adolescents school and socioemotional adjustment. Journal of Personality, 71, 1197-1232.

Wright, S. C., Aron, A., Mclaughlin-Volpe, T., \& Ropp, S. A. (1997). The extended contact effect: Knowledge of cross-group friendships and prejudice. Journal of Personality and Social Psychology, 73, 73-90. 